\title{
In Vitro Antimicrobial Activity of Extracts from Plants Used Traditionally in South Africa to Treat Tuberculosis and Related Symptoms
}

\author{
Balungile Madikizela, Ashwell Rungano Ndhlala, \\ Jeffrey Franklin Finnie, and Johannes Van Staden
}

Research Centre for Plant Growth and Development, School of Life Sciences, University of KwaZulu-Natal Pietermaritzburg, Private Bag X01, Scottsville 3209, South Africa

Correspondence should be addressed to Johannes Van Staden; rcpgd@ukzn.ac.za

Received 12 November 2012; Accepted 23 January 2013

Academic Editor: Seong-Gyu Ko

Copyright (C) 2013 Balungile Madikizela et al. This is an open access article distributed under the Creative Commons Attribution License, which permits unrestricted use, distribution, and reproduction in any medium, provided the original work is properly cited.

Respiratory ailments are major human killers, especially in developing countries. Tuberculosis (TB) is an infectious disease causing a threat to human healthcare. Many South African plants are used in the traditional treatment of TB and related symptoms, but there has not been a sufficient focus on evaluating their antimicrobial properties. The aim of this study was to evaluate the antimicrobial properties of plants used traditionally to treat TB and related symptoms against microorganisms (Klebsiella pneumoniae, Staphylococcus aureus, and Mycobacterium aurum A+) associated with respiratory infections using the microdilution assay. Ten plants were selected based on a survey of available literature of medicinal plants used in South Africa for the treatment of TB and related symptoms. The petroleum ether, dichloromethane, $80 \%$ ethanol, and water extracts of the selected plants were evaluated for antibacterial activity. Out of 68 extracts tested from different parts of the 10 plant species, 17 showed good antimicrobial activities against at least one or more of the microbial strains tested, with minimum inhibitory concentration ranging from 0.195 to $12.5 \mathrm{mg} / \mathrm{mL}$. The good antimicrobial properties of Abrus precatorius, Terminalia phanerophlebia, Indigofera arrecta, and Pentanisia prunelloides authenticate their traditional use in the treatment of respiratory diseases. Thus, further pharmacological and phytochemical analysis is required.

\section{Introduction}

A few decades ago, there was enormous optimism about the decline of threatening infectious diseases due to advances in technology and science [1]. However, due to a rise in the transitional nature of infectious diseases, such optimism has not yet been met. Worldwide infectious diseases are still the leading cause of death, especially in developing countries, claiming millions of lives yearly despite the enormous improvements made in human healthcare [2]. Globally, infectious diseases are the second leading cause of death of children and adults under the age of 50, placing severe burdens on the developing world $[3,4]$. Within the last few decades, there has been the emergence of about 30 threatening infectious diseases with the majority capable of affecting humans [4]. The treatment of infectious diseases is facing a major problem at present with many microbes developing resistance to widely used antibiotics and antiviral therapies [5-7]. A few examples are the pathogens associated with acquired immunodeficiency syndrome (AIDS) and multidrug-resistant TB (MDRTB). In the coming years, emerging diseases will probably increase due to travel, urbanization, overcrowding, and inadequate healthcare leading to new interactions between human beings and animals as well as other diseases [8]. Thus, addressing the problem of infectious diseases is now an important and urgent requirement.

Respiratory diseases are among the major human killers in the world [9]. TB has been reported to be one of the most serious infectious bacterial diseases, causing a threat to healthcare globally despite the availability of drugs and 
care centres since the 1940 s $[7,9-11]$. TB is the most common cause of morbidity and mortality especially when coinfection with HIV-1 occurs and is a pandemic in many parts of the world [12]. TB is the most commonly notified disease in South Africa and the fifth largest cause of death $[13,14]$. Approximately 285,000 cases of TB were estimated in South Africa in 2005, and it had the seventh highest population with $\mathrm{TB}$ in the world and the second in Africa [14].

Due to the important role medicinal plants play in the process of drug discovery and development, they are widely recognised as sources of active antimicrobial metabolites [11]. Several studies have been carried out in South Africa to record the ethnobotanical uses of plants in the treatment of tuberculosis and related symptoms such as coughing, respiratory ailments, and fever [11]. Examples of such detailed studies are recorded in useful reviews of medicinal plants by Watt and Breyer-Brandwijk [36]; Hutchings et al. [15], as well as Van Wyk et al. [17, 29]. Thus, there is a great potential in finding medicinal plants with activity against microorganisms related to respiratory infections.

Most studies done in South Africa on plants used traditionally to treat respiratory ailments have focused on evaluating their antimycobacterial activity against TB causing bacterial strains $[13,14,37]$ but with little emphasis on the related symptoms $[38,39]$. Therefore, this current study was aimed at evaluating the antimicrobial activity of selected plants against bacteria related to respiratory infection.

\section{Materials and Methods}

2.1. Selection and Preparation of Plants for Bioassays. Ten plants were selected based on the available literature of medicinal plants used by various South African tribes in the treatment of TB and related symptoms [11, 15, 17, 20, 29]. The plant materials were collected from the University of KwaZulu-Natal Botanical Garden and Ukulinga Research Farm. Voucher specimens were deposited in the University of KwaZulu-Natal (Pietermaritzburg) Herbarium (NU) for botanical authentication. The species name, family, traditional uses, voucher numbers, parts used, and previously screened activity of the plants used in the study are given in Table 1 . The plant materials were oven-dried at $50^{\circ} \mathrm{C}$, ground into powders, and stored in airtight containers. Dried plant material (10 g) was extracted sequentially with $200 \mathrm{~mL}$ of each of the four solvents, petroleum ether (PE), dichloromethane (DCM), 80\% ethanol (EtOH), and water (from polar to nonpolar) by sonication for $1 \mathrm{~h}$ at $15^{\circ} \mathrm{C}$ with temperature being maintained by the addition of ice. The samples were then filtered through Whatman No. 1 filter paper and concentrated to dryness under reduced pressure using a rotary evaporator to obtain crude extracts. The aqueous extracts were dried under reduced pressure by means of a freeze-drier. Crude extracts were then stored in the dark at $10^{\circ} \mathrm{C}$ until use. The percentage yield for each extract was determined.

2.2. Bacterial Strains and Culture Conditions. Three strains of bacteria were used for antibacterial evaluation against the extracts. The strains were Klebsiella pneumoniae (ATCC
13883), Staphylococcus aureus (ATCC 12600), which were obtained from the American type culture collection, and Mycobacterium aurum A+ from the Microbiology Laboratory, Division of Pharmacology, University of Cape Town. The test organisms were selected because of their respiratory pathogenesis and fast growth rates $[14,40]$. The strains were maintained on Mueller-Hinton ( $\mathrm{MH}$ ) agar except for $M$. aurum A+ which was maintained on Middlebrook 7H10 agar supplemented with $0.5 \%$ glycerol and $10 \%$ OADC (oleic acid, albumin, dextrose, and catalase).

2.3. Antimicrobial Activity Assays. The minimum inhibitory concentrations (MIC) of plant extracts were determined using the broth microdilution method in 96-well microtitre plates for $S$. aureus and $K$. pneumoniae as described by Eloff [41] and Jadaun et al. [42] for M. aurum A+. The extracts were dissolved in $10 \%$ DMSO except for aqueous extracts which were dissolved in sterile distilled water. The test organisms (S. aureus and K. pneumoniae) were cultured in $\mathrm{MH}$ broth for $24 \mathrm{~h}$, while Middlebrook broth supplemented with $10 \%$ OADC and $0.5 \%$ glycerol was used to culture $M$. aurum A+ for $72 \mathrm{~h}$ at $37^{\circ} \mathrm{C}$. Neomycin and streptomycin were used as the positive controls whereas broth, $10 \%$ DMSO, and water were used as negative controls. For antibacterial testing against S. aureus and K. pneumonia, $100 \mu \mathrm{L}$ of water were added in each well and Middlebrook broth supplemented with $0.5 \%$ glycerol, and 10\% OADC was used for M. aurum A+. One hundred microliters of solvent controls and test samples were added to the first wells of the microplate starting with a concentration of $100 \mathrm{mg} / \mathrm{mL}$ of extracts and $5 \mathrm{mg} / \mathrm{mL}$ for the positive control and then two-fold serially diluted down the wells. The optical density of $S$. aureus and K. pneumoniae was adjusted with $\mathrm{MH}$ broth to match that of McFarland standard, equivalent to $10^{8}$ colony forming units at $600 \mathrm{~nm}$, and that of M. aurum A+ was adjusted to 0.125 at $550 \mathrm{~nm}$ using Middlebrook broth enriched with $0.5 \%$ glycerol and $10 \%$ OADC growth supplement. One hundred microliters of the diluted culture were added to all the wells. The microtitre plates were then incubated for $24 \mathrm{~h}$ at $37^{\circ} \mathrm{C}(S$. aureus and K. pneumoniae) and for $72 \mathrm{~h}$ at $37^{\circ} \mathrm{C}$ (M. aurum $\mathrm{A}+)$. After incubation, $40 \mu \mathrm{L}$ of $p$-iodonitrotetrazolium violet (INT) indicator (S. aureus and K. pneumoniae) and resazurin (M. aurum $\mathrm{A}+$ ) were added to evaluate growth inhibition. The results were observed after $30 \mathrm{~min}$ for $S$. aureus and $K$. pneumoniae and $24 \mathrm{~h}$ for $M$. aurum $\mathrm{A}+$. The lowest concentration containing blue (M. aurum A+) and clear wells (S. aureus and K. pneumoniae) were considered as the MIC values. The assay was repeated twice with two replicates per assay.

\section{Results and Discussion}

The plants selected in this study are all used in South African traditional medicine for the treatment of TB and related symptoms. The percentage yield and MIC values of the plant extract against $K$. pneumoniae, S. aureus and $M$. aurum $\mathrm{A}+$ are presented in Table 2 . The highest quantity of extract yield was observed from the EtOH extract of 
TABLE 1: Medicinal plants used traditionally in South Africa to treat TB and related symptoms.

\begin{tabular}{|c|c|c|c|c|c|}
\hline Family, species & $\begin{array}{c}\text { Voucher specimen } \\
\text { number }\end{array}$ & Traditional use & Parts used & Previously screened activity & References \\
\hline $\begin{array}{l}\text { Amaryllidaceae } \\
\text { Brunsvigia } \\
\text { grandiflora } \\
\text { Lindl. }\end{array}$ & BALUNGI 31 & Coughs and colds & Bulbs & $\begin{array}{l}\text { Mutagenic and } \\
\text { antimutagenic activities of } \\
\text { bulbs }\end{array}$ & {$[15,16]$} \\
\hline $\begin{array}{l}\text { Asparagaceae } \\
\text { Asparagus africanus } \\
\text { Lam. }\end{array}$ & BALUNGI 36 & Tuberculosis & Shoots & $\begin{array}{l}\text { Analgesic and } \\
\text { anti-inflammatory } \\
\text { activities of roots. Two } \\
\text { antiprotozoal compounds } \\
\text { were isolated }\end{array}$ & {$[15,17-19]$} \\
\hline $\begin{array}{l}\text { Asparagaceae } \\
\text { Asparagus falcatus } \\
\text { (L.) Oberm. }\end{array}$ & BALUNGI 44 & Tuberculosis & Leaves, roots & $\begin{array}{l}\text { Caryophyllene-type } \\
\text { sesquiterpene lactone } \\
\text { isolated from the leaves was } \\
\text { found to have remarkable } \\
\text { effect on the proliferation } \\
\left(\mathrm{IC}_{50} 1.82 \mathrm{uM}\right) \text {. } \\
\text { Antibacterial activity of the } \\
\text { roots }\end{array}$ & {$[20-22]$} \\
\hline $\begin{array}{l}\text { Fabaceae } \\
\text { Abrus precatorius } \\
\text { subsp. africanus } \\
\text { Verdc. }\end{array}$ & BALUNGI 43 & $\begin{array}{l}\text { Tuberculosis, } \\
\text { bronchitis, } \\
\text { whooping cough, chest } \\
\text { complaints, and asthma }\end{array}$ & Leaves, roots & $\begin{array}{l}\text { Sedative effects of roots. } \\
\text { Antibacterial and } \\
\text { cytotoxicity activity of } \\
\text { seeds. Five compounds } \\
\text { were isolated and identified } \\
\text { as isoflavan, quinones, and } \\
\text { hydroquinones }\end{array}$ & {$[15,23-26]$} \\
\hline $\begin{array}{l}\text { Combretaceae } \\
\text { Terminalia } \\
\text { phanerophlebia Engl. } \\
\text { \& Diels }\end{array}$ & BALUNGI 37 & Tuberculosis & Roots & $\begin{array}{l}\text { Antibacterial and } \\
\text { antifungal activities of the } \\
\text { leaves }\end{array}$ & {$[20,27]$} \\
\hline $\begin{array}{l}\text { Leguminosae } \\
\text { Indigofera arrecta } \\
\text { Benth. ex Harv. \& } \\
\text { Sond. }\end{array}$ & BALUNGI 41 & Tuberculosis & Root & $\begin{array}{l}\text { Antibacterial activity of the } \\
\text { leaves }\end{array}$ & {$[20,28]$} \\
\hline $\begin{array}{l}\text { Moraceae } \\
\text { Ficus sur Forssk. }\end{array}$ & BALUNGI 39 & $\begin{array}{l}\text { Tuberculosis/ulceration } \\
\text { of the lung }\end{array}$ & Bark, root & $\begin{array}{l}\text { Antimalarial and } \\
\text { antibacterial activities of } \\
\text { the leaves. }\end{array}$ & {$[15,29-31]$} \\
\hline $\begin{array}{l}\text { Polygalaceae } \\
\text { Polygala fruticosa P. J. } \\
\text { Bergius }\end{array}$ & BALUNGI 35 & $\begin{array}{l}\text { Tuberculosis, blood } \\
\text { purification, intestinal } \\
\text { sores,sinusitis, and } \\
\text { gonorrhoea }\end{array}$ & Whole plant & $\begin{array}{l}\text { Antibacterial activity } \\
\text { against Gardnerella } \\
\text { vaginalis and toxicity }\end{array}$ & {$[11,29,32,33]$} \\
\hline $\begin{array}{l}\text { Rubiaceae } \\
\text { Pentanisia } \\
\text { prunelloides } \\
\text { Schinz }\end{array}$ & $\begin{array}{l}\text { BALUNGI } 40 \\
\text { and } 42\end{array}$ & $\begin{array}{l}\text { Tuberculosis, chest } \\
\text { pain, fever, and } \\
\text { toothache }\end{array}$ & Root & $\begin{array}{l}\text { Antibacterial activity } \\
\text { against } B . \text { subtilis, S. aureus, } \\
\text { E. coli,and } K \text {. pneumonia. } \\
\text { Antiviral activity of leaves } \\
\text { and roots }\end{array}$ & {$[15,29,34]$} \\
\hline $\begin{array}{l}\text { Lamiaceae } \\
\text { Leonotis intermedia } \\
\text { Lindl. }\end{array}$ & BALUNGI 38 & $\begin{array}{l}\text { Colds, coughs, } \\
\text { bronchitis, } \\
\text { asthma, tuberculosis, } \\
\text { high blood pressure, } \\
\text { and jaundice }\end{array}$ & Leaves, stem & Anti-inflammatory activity & {$[11,35]$} \\
\hline
\end{tabular}


TABLE 2: The antibacterial (MIC values) effects of plants used traditionally as remedies for the treatment of tuberculosis and related symptoms in South Africa.

\begin{tabular}{|c|c|c|c|c|c|c|}
\hline \multirow{2}{*}{ Plant species } & \multirow{2}{*}{ Plant part } & \multirow{2}{*}{ Extract } & \multirow{2}{*}{ Extract yield \% (DW) } & \multicolumn{3}{|c|}{ Antibacterial activity MIC $(\mathrm{mg} / \mathrm{mL})$} \\
\hline & & & & $\begin{array}{c}\text { Klebsiella } \\
\text { pneumoniae }\end{array}$ & $\begin{array}{c}\text { Mycobacterium } \\
\text { aurum } \mathrm{A}+\end{array}$ & $\begin{array}{c}\text { Staphylococcus } \\
\text { aureus }\end{array}$ \\
\hline \multirow{8}{*}{ A. precatorius subsp. africanus } & \multirow{4}{*}{$\mathrm{L}$} & $\mathrm{PE}$ & 1.03 & 12.50 & 12.50 & 12.50 \\
\hline & & $\mathrm{DCM}$ & 1.24 & 12.50 & 0.78 & 12.50 \\
\hline & & $80 \% \mathrm{EtOH}$ & 3.54 & 3.13 & 0.195 & 1.56 \\
\hline & & Water & 2.66 & 6.25 & 12.50 & 3.13 \\
\hline & \multirow{4}{*}{$\mathrm{S}$} & $\mathrm{PE}$ & 2.28 & 12.50 & 12.50 & 6.25 \\
\hline & & DCM & 2.87 & 12.50 & 6.25 & 3.13 \\
\hline & & $80 \% \mathrm{EtOH}$ & 3.42 & 6.25 & 0.78 & 1.56 \\
\hline & & Water & 2.43 & 1.56 & 1.56 & 3.13 \\
\hline \multirow{4}{*}{ A. africanus } & \multirow{4}{*}{$\mathrm{L}$} & PE & 0.40 & 12.50 & 6.25 & 12.50 \\
\hline & & DCM & 0.50 & 12.50 & 6.25 & 12.50 \\
\hline & & $80 \% \mathrm{EtOH}$ & 1.50 & 6.25 & 0.39 & 6.25 \\
\hline & & Water & 6.80 & 1.56 & 6.25 & 12.50 \\
\hline \multirow{4}{*}{ A. falcatus } & \multirow{4}{*}{$\mathrm{L}$} & $\mathrm{PE}$ & 0.80 & 12.50 & 3.13 & 12.50 \\
\hline & & DCM & 0.62 & 12.50 & 1.56 & 12.50 \\
\hline & & $80 \% \mathrm{EtOH}$ & 2.76 & 6.25 & 0.39 & 3.13 \\
\hline & & Water & 1.00 & 3.13 & 2.56 & 1.56 \\
\hline \multirow{4}{*}{ B. grandiflora } & \multirow{4}{*}{$\mathrm{Bb}$} & $\mathrm{PE}$ & 2.83 & 12.50 & 12.50 & 12.50 \\
\hline & & DCM & 0.98 & 12.50 & 3.13 & 6.25 \\
\hline & & $80 \% \mathrm{EtOH}$ & 4.47 & 3.13 & 3.13 & 6.25 \\
\hline & & Water & 3.42 & 3.13 & 3.13 & 6.25 \\
\hline \multirow{8}{*}{ F. sur } & \multirow{4}{*}{$\mathrm{B}$} & $\mathrm{PE}$ & 0.50 & 12.50 & 6.25 & 12.50 \\
\hline & & DCM & 0.50 & 12.50 & 6.35 & 12.50 \\
\hline & & $80 \% \mathrm{EtOH}$ & 0.60 & 6.25 & 3.13 & 6.25 \\
\hline & & Water & 0.40 & 6.25 & 6.25 & 12.50 \\
\hline & \multirow{4}{*}{$\mathrm{R}$} & $\mathrm{PE}$ & 3.20 & 6.25 & 12.5 & 12.50 \\
\hline & & DCM & 0.70 & 6.25 & 6.25 & 12.50 \\
\hline & & $80 \% \mathrm{EtOH}$ & 7.70 & 0.78 & 3.13 & 0.195 \\
\hline & & Water & 2.10 & 12.50 & 3.13 & 3.13 \\
\hline \multirow{8}{*}{ I. arrecta } & \multirow{4}{*}{$\mathrm{L}$} & PE & 2.66 & 6.25 & 12.50 & 12.50 \\
\hline & & DCM & 1.79 & 12.50 & 6.25 & 12.50 \\
\hline & & $80 \% \mathrm{EtOH}$ & 11.15 & 0.78 & 0.39 & 0.39 \\
\hline & & Water & 9.69 & 12.50 & 0.78 & 6.25 \\
\hline & \multirow{4}{*}{$\mathrm{R}$} & $\mathrm{PE}$ & 0.60 & 12.50 & 6.25 & 12.50 \\
\hline & & DCM & 0.70 & 12.50 & 1.56 & 12.50 \\
\hline & & $80 \% \mathrm{EtOH}$ & 11.40 & 3.13 & 1.56 & 1.56 \\
\hline & & Water & 0.80 & 6.35 & 12.50 & 12.50 \\
\hline \multirow{8}{*}{ L. intermedia } & \multirow{4}{*}{$\mathrm{L}$} & $\mathrm{PE}$ & 1.02 & 12.50 & 6.25 & 12.50 \\
\hline & & DCM & 1.00 & 12.50 & 12.50 & 12.50 \\
\hline & & $80 \% \mathrm{EtOH}$ & 5.62 & 6.25 & 0.195 & 0.78 \\
\hline & & Water & 3.20 & 3.13 & 3.13 & 1.56 \\
\hline & \multirow{4}{*}{ St } & $\mathrm{PE}$ & 0.50 & 6.25 & 3.13 & 12.50 \\
\hline & & DCM & 0.60 & 6.25 & 12.50 & 12.50 \\
\hline & & $80 \% \mathrm{EtOH}$ & 4.80 & 3.13 & 1.56 & 1.56 \\
\hline & & Water & 3.00 & 3.13 & 1.56 & 6.25 \\
\hline
\end{tabular}


TABLE 2: Continued.

\begin{tabular}{|c|c|c|c|c|c|c|}
\hline \multirow{2}{*}{ Plant species } & \multirow{2}{*}{ Plant part } & \multirow{2}{*}{ Extract } & \multirow{2}{*}{ Extract yield \% (DW) } & \multicolumn{3}{|c|}{ Antibacterial activity MIC $(\mathrm{mg} / \mathrm{mL})$} \\
\hline & & & & $\begin{array}{c}\text { Klebsiella } \\
\text { pneumoniae }\end{array}$ & $\begin{array}{c}\text { Mycobacterium } \\
\text { aurum A+ }\end{array}$ & $\begin{array}{c}\text { Staphylococcus } \\
\text { aureus }\end{array}$ \\
\hline \multirow{8}{*}{ P. prunelloides } & \multirow{4}{*}{$\mathrm{L}$} & $\mathrm{PE}$ & 1.30 & 6.25 & 6.25 & 12.50 \\
\hline & & DCM & 1.40 & 12.50 & 12.50 & 6.25 \\
\hline & & $80 \% \mathrm{EtOH}$ & 4.40 & 3.13 & 0.39 & 0.195 \\
\hline & & Water & 1.50 & 3.13 & 1.56 & 0.39 \\
\hline & \multirow{4}{*}{$\mathrm{R}$} & PE & 0.20 & 6.25 & 3.13 & 12.50 \\
\hline & & DCM & 0.20 & 6.25 & 12.50 & 12.50 \\
\hline & & $80 \% \mathrm{EtOH}$ & 11.40 & 0.39 & 0.78 & 0.78 \\
\hline & & Water & 6.76 & 1.56 & 1.56 & 1.56 \\
\hline \multirow{4}{*}{ P. fruticosa } & \multirow{4}{*}{$\mathrm{Wp}$} & $\mathrm{PE}$ & 0.73 & 6.25 & 1.56 & 6.25 \\
\hline & & DCM & 1.04 & 6.25 & 1.56 & 6.25 \\
\hline & & $80 \% \mathrm{EtOH}$ & 16.67 & 3.13 & 3.13 & 1.56 \\
\hline & & Water & 4.84 & 3.13 & 3.13 & 6.25 \\
\hline \multirow{12}{*}{ T. phanerophlebia } & \multirow{4}{*}{$\mathrm{L}$} & $\mathrm{PE}$ & 0.50 & 6.25 & 6.25 & 6.25 \\
\hline & & DCM & 1.20 & 6.25 & 6.25 & 6.25 \\
\hline & & $80 \% \mathrm{EtOH}$ & 16.00 & 0.195 & 1.56 & 0.195 \\
\hline & & Water & 9.80 & 0.39 & 0.39 & 0.098 \\
\hline & \multirow{4}{*}{$\mathrm{R}$} & $\mathrm{PE}$ & 0.10 & 12.50 & 6.25 & 12.50 \\
\hline & & DCM & 0.30 & 6.25 & 3.13 & 6.25 \\
\hline & & $80 \% \mathrm{EtOH}$ & 12.90 & 1.56 & 3.13 & 0.195 \\
\hline & & Water & 1.70 & 3.13 & 6.25 & 0.39 \\
\hline & \multirow{4}{*}{$\mathrm{T}$} & $\mathrm{PE}$ & 1.00 & 6.25 & 3.13 & 6.25 \\
\hline & & DCM & 0.40 & 6.25 & 1.56 & 3.13 \\
\hline & & $80 \% \mathrm{EtOH}$ & 11.00 & 0.195 & 0.195 & 0.39 \\
\hline & & Water & 3.70 & 1.56 & 1.56 & 1.56 \\
\hline Neomycin & & & & 0.0975 & & 0.0975 \\
\hline Streptomycin & & & & & 0.195 & \\
\hline
\end{tabular}

L: leaves, R: roots, B: bark, Bb: bulb, S: seeds, St: stem, Wp: whole plant, T: twigs, MIC: minimum inhibitory concentration, DCM: dichloromethane, PE: petroleum ether, EtOH: ethanol, \% DW: percentage dry weight Values boldly written are considered very active.

P. fruticosa, whilst the lowest one was from PE extracts of the roots of T. phanerophlebia. Generally, EtOH was the best extractant giving the highest mass of extracts while PE yielded the lowest mass. The masses of the water extracts were the second highest to EtOH for most of the species extracted. In this study, only MIC values equal to or less than $1.0 \mathrm{mg} / \mathrm{mL}$ for crude extracts were considered as exhibiting good activity [43]. Out of 68 extracts tested from different parts of 10 species, 17 were found to have good antimicrobial activities at least against one or more of the strains tested. Twelve extracts showed good activity against $M$. aurum $\mathrm{A}+$ and 11 against $S$. aureus. It was observed that $M$. aurum $\mathrm{A}+$ was the most susceptible bacterium while $K$. pneumoniae was the most resistant with only 6 extracts showing good activity. Due to lipopolysaccharides present on their outer membrane, Gram-negative bacteria are usually impermeable to most antibacterial compounds [44, 45]. This can explain the low number of active extracts against K. pneumoniae.
The water extract of T. phanerophlebia (leaf) showed the best activity with the lowest MIC value of $0.098 \mathrm{mg} / \mathrm{mL}$ among the extracts tested. For water extracts only $T$. phanerophlebia leaves exhibited good activity against all bacterial species tested with MIC values ranging from 0.098 to $0.39 \mathrm{mg} / \mathrm{mL}$. The water extracts of I. arrecta (leaf), P. prunelloides (leaf), and T. phanerophlebia (root) also showed good activity against at least one bacterial strain with MIC values ranging from 0.39 to $0.78 \mathrm{mg} / \mathrm{mL}$. This was encouraging as many reports often state that water extracts lack bioactivity [46]. The evaluation of aqueous extracts aims to mimic the traditional use; therefore, the observed antibacterial activities exhibited by water extracts could be of interest. Such plants are candidates for further studies such as antimycobacterial evaluation against TB causing bacterial strains.

Comparing the root and leaf extracts of I. arrecta, the EtOH extracts of the leaf showed good antibacterial activity against all bacterial species tested with MIC values ranging from 0.39 to $0.78 \mathrm{mg} / \mathrm{mL}$. For $P$. prunelloides leaves and 
roots, the EtOH extracts showed good activity with MIC values ranging from 0.195 to $0.78 \mathrm{mg} / \mathrm{mL}$ against almost all bacterial species tested. This is noteworthy as it indicates the presence of bioactive compounds in these plants that might help to isolate drugs that cure ailments related to respiratory infection. The palmitic acid previously isolated from roots of $P$. prunelloides by Yff et al. [34] could be responsible for the antimicrobial activity of this plant observed in this study. Yff et al. [34] also did an antiviral test on the root decoction of $P$. prunelloides and reported the inhibition of Influenza A virus. These results make this plant a potentially effective remedy against respiratory diseases, and the evaluation of palmitic acid against respiratory microbes is required.

For T. phanerophlebia leaf, root, and twig extracts, the EtOH extracts showed good activity against almost all bacterial strains tested with MIC values ranging from 0.098 to $0.39 \mathrm{mg} / \mathrm{mL}$. This, however, was excluding the leaf extract that did not exhibit good activity against one strain and root extract that also did not show good activity against two strains. In a study on antimicrobial properties done by Shai et al. [27] against S. aureus, Escherichia coli, Enterococcus faecalis, and Pseudomonas aeruginosa, the leaf extracts of $T$. phanerophlebia exhibited good antimicrobial activity which was also the case in our study against the tested bacteria. In addition, in a literature investigation conducted by Nair et al. [47], several alkaloids were reported to have been isolated from the stem of T. phanerophlebia which exhibited cyclooxygenase- 2 enzyme activity. The antimicrobial activity observed from different parts of this plant might be due to those alkaloids (cholestane triterpenoids $\beta$-sitostenone, stigmast-4-ene-3,6-dione, and $\beta$-sitosterol). It is, therefore, important to evaluate these compounds in bioassays against these microorganisms. Among the bark and root extracts of F. sur, only the EtOH extract (root) showed good activity with an MIC value of $0.78 \mathrm{mg} / \mathrm{mL}$ against $K$. pneumoniae and $0.195 \mathrm{mg} / \mathrm{mL}$ against $S$. aureus. The activity of this plant could be due to the triterpene compounds found in the latex isolated in a previous study by Feleke and Brehane [48], which also warrants testing in similar bioassays.

Among the leaf and stem of L. intermedia, the EtOH extract (leaf) showed good activity with MIC value of 0.195 against $M$. aurum $\mathrm{A}+$ and 0.78 against $S$. aureus. These findings are very interesting as they indicate the antimicrobial activity of this plant. Of all the extracts of $A$. africanus and $A$. falcatus, good activity was observed only in the EtOH extracts with both having an MIC value of $0.39 \mathrm{mg} / \mathrm{mL}$ against $M$. aurum A+. Asparagus species are known to have steroidal saponins as their major bioactive constituents; therefore, the antimycobacterial activity of these two species of Asparagus could be due to saponins [49]. However, among all extracts of the leaves and seeds of $A$. precatorius subsp. africanus, only the EtOH (leaves and seeds) and DCM extracts (leaves) showed good activity with MIC values ranging from 0.195 to $0.78 \mathrm{mg} / \mathrm{mL}$ against $M$. aurum A+ only. Phytochemical research done in a previous study by Taur and Patil [50] from the root and aerial part of this plant showed the presence of triterpenoids and saponins. Saponins are known to have broad spectrum of pharmacological activities, including antimicrobial properties [51]. In view of the fact that these plants were selected based on their traditional uses against $\mathrm{TB}$ and related symptoms, these findings are noteworthy. However, all the extracts of B. grandiflora and P. fruticosa did not show good activity against all bacterial species tested despite being reported to be used in the treatment of TB and related symptoms. However, bioactivity cannot be completely ruled out from such plant species as they could be active against other bacterial strains that cause respiratory ailments. The other possible explanation could be that antimicrobial effects of these plants are not mediated through direct inhibition on microbial growth but rather through immunostimulation or the compounds potentially active require metabolic activation by certain enzyme in vivo [52].

\section{Conclusion}

Two or more extracts of $A$. precatorius subsp. africanus, $T$. phanerophlebia, I. arrecta, and P. prunelloides showed good antimicrobial activity against at least one or more of the bacterial strains tested. Therefore, the good antimicrobial properties of $A$. precatorius subsp. africanus, T. phanerophlebia, I. arrecta, and $P$. prunelloides found in this study form a good basis for further pharmacological (such as antimycobacterial evaluation against infectious TB microorganisms) and phytochemical investigation, and they validate the traditional use of these plants in the treatment of respiratory diseases in South Africa. The fact that some species of plants did not display good antimicrobial activity does not mean that they may have the same effect in vivo; thus, it should be noted that they only demonstrated weak activity in vitro. Additionally, weak activity might mean that the plant species are used to treat the symptoms of various respiratory ailments rather than the disease itself.

\section{Acknowledgments}

The National Research Foundation (NRF), Pretoria, Canon Collins GreenMatter Fellowship, Claude Leon Foundation, and the University of KwaZulu-Natal (UKZN) are thanked for providing financial support. The authors also wish to acknowledge Mrs. Alison Young (Horticulturist, UKZN) and Dr. Christina Curry, (Herbarium, NU) for the help in plant identification and the handling of herbarium specimens.

\section{References}

[1] M. L. Cohen, "Resurgent and emergent disease in a changing world," British Medical Bulletin, vol. 54, no. 3, pp. 523-532, 1998.

[2] T. York, H. de Wet, and S. F. Van Vuuren, "Plants used for treating respiratory infections in rural Maputaland, KwaZuluNatal, South Africa," Journal of Ethnopharmacology, vol. 135, no. 3, pp. 696-710, 2011.

[3] A. S. Fauci, "Infectious diseases: considerations for the 21st century," Clinical Infectious Diseases, vol. 32, no. 5, pp. 675-685, 2001.

[4] M. A. Hamburg, "Considerations for infectious disease research and practice," Technology in Society, vol. 30, no. 3-4, pp. 383-387, 2008 . 
[5] D. M. Morens, G. K. Folkers, and A. S. Fauci, "The challenge of emerging and re-emerging infectious diseases," Nature, vol. 430, no. 6996, pp. 242-249, 2004.

[6] M. V. N. de Souza, "Promising candidates in clinical trials against multidrug-resistant tuberculosis (MDR-TB) based on natural products," Fitoterapia, vol. 80, no. 8, pp. 453-460, 2009.

[7] Y. L. Chen, S. T. Huang, F. M. Sun et al., "Transformation of cinnamic acid from trans- to cis-form raises a notable bactericidal and synergistic activity against multiple-drug resistant Mycobacterium tuberculosis," European Journal of Pharmaceutical Sciences, vol. 43, no. 3, pp. 188-194, 2011.

[8] E. Alirol, L. Getaz, B. Stoll, F. Chappuis, and L. Loutan, "Urbanisation and infectious diseases in a globalised world," The Lancet Infectious Diseases, vol. 11, no. 2, pp. 131-141, 2011.

[9] A. Mann, J. O. Amupitan, A. O. Oyewale et al., "Evaluation of in vitro antimycobacterial activity of Nigerian plants used for treatment of respiratory diseases," African Journal of Biotechnology, vol. 7, no. 11, pp. 1630-1636, 2008.

[10] M. D. R. Camacho-Corona, M. A. Ramírez-Cabrera, O. González-Santiago, E. Garza-González, I. D. P. Palacios, and J. Luna-Herrera, "Activity against drug resistant-tuberculosis strains of plants used in Mexican traditional medicine to treat tuberculosis and other respiratory diseases," Phytotherapy Research, vol. 22, no. 1, pp. 82-85, 2008.

[11] L. J. McGaw, N. Lall, J. J. M. Meyer, and J. N. Eloff, "The potential of South African plants against Mycobacterium infections," Journal of Ethnopharmacology, vol. 119, no. 3, pp. 482-500, 2008.

[12] N. R. Gandhi, A. Moll, A. W. Sturm et al., "Extensively drugresistant tuberculosis as a cause of death in patients co-infected with tuberculosis and HIV in a rural area of South Africa," The Lancet, vol. 368, no. 9547, pp. 1575-1580, 2006.

[13] N. Lall and J. M. Meyer, "In vitro inhibition of drug-resistant and drug-sensitive strains of Mycobacterium tuberculosis by ethnobotanically selected South African plants," Journal of Ethnopharmacology, vol. 66, no. 3, pp. 347-354, 1999.

[14] E. Green, A. Samie, C. L. Obi, P. O. Bessong, and R. N. Ndip, "Inhibitory properties of selected South African medicinal plants against Mycobacterium tuberculosis," Journal of Ethnopharmacology, vol. 130, no. 1, pp. 151-157, 2010.

[15] A. Hutchings, A. H. Scott, G. Lewis, and A. Cunningham, Zulu Medicinal Plants. An Inventory, University of Natal Press, Pietermaritzburg, South Africa, 1962.

[16] L. Verschaeve and J. Van Staden, "Mutagenic and antimutagenic properties of extracts from South African traditional medicinal plants," Journal of Ethnopharmacology, vol. 119, no. 3, pp. 575587, 2008.

[17] B.-E. Van Wyk, B. Van Oudtshoorn, and N. Gericke, Medicinal Plants of South Africa, Briza Publications, Pretoria, South Africa, 2nd edition, 2009.

[18] H. A. Oketch-Rabah, S. F. Dossaji, S. B. Christensen et al., "Antiprotozoal compounds from Asparagus africanus," Journal of Natural Products, vol. 60, no. 10, pp. 1017-1022, 1997.

[19] H. S. Hassan, A. A. Ahmadu, and A. S. Hassan, "Analgesic and anti-inflammatory activities of Asparagus africanus root extract," African Journal of Traditional, Complementary and Alternative Medicines, vol. 5, no. 1, pp. 27-31, 2008.

[20] D. Mabogo, The ethnobotany of the Vha-Venda [M.S. thesis], University of Pretoria, Pretoria, South Africa, 1990.

[21] V. Steenkamp, A. C. Fernandes, and C. E. van Rensburg, "Antibacterial activity of Venda medicinal plants," Fitoterapia, vol. 78, no. 7-8, pp. 561-564, 2007.
[22] R. M. . Ghalib, R. Hashim, O. Sulaiman et al., "A novel caryophyllene type sesquiterpene lactone from Asparagus falcatus (Linn.) structure elucidation and anti-angiogenic activity on huvecs," European Journal of Medicinal Chemistry, vol. 47, no. 1, pp. 601-607, 2012.

[23] G. B. Zore, V. Awad, A. D. Thakre et al., "Activity-directed fractionation and isolation of four antibacterial compounds from Abrus precatorius L. roots," Natural Product Research, vol. 21, no. 10, pp. 933-940, 2007.

[24] R. Sivakumar and C. Alagesaboopathi, "Studies on cytotoxicity and antitumor screening of red and white forms of Abrus precatorius L," African Journal of Biotechnology, vol. 7, no. 22, pp. 3984-3988, 2008.

[25] G. E. K. Bolou, I. Bagré, K. Ouattara, and A. J. Djaman, "Evaluation of the antibacterial activity of 14 medicinal plants in côte d'ivoire," Tropical Journal of Pharmaceutical Research, vol. 10, no. 3, pp. 335-340, 2011.

[26] Y. Hata, M. Raith, S. N. Ebrahimi et al., "Antiprotozoal isoflavan quinones from Abrus precatorius," Planta Medica, vol. 78, no. 11, pp. 1277-1277, 2012.

[27] L. J. Shai, L. J. McGaw, P. Masoko, and J. N. Eloff, "Antifungal and antibacterial activity of seven traditionally used South African plant species active against Candida albicans," South African Journal of Botany, vol. 74, no. 4, pp. 677-684, 2008.

[28] J. C. Tomani, J. P. Nkurunziza, and M. J. Mukazayire, "Antidiarrhea activity and preliminary phytochemical screening of Indigofera arrecta, Cyathula uncinulata, Persea americana and Cupressus lusitanica," Planta Medica, vol. 74, no. 9, pp. 956-956, 2008.

[29] B.-E. Van Wyk, B. Van Oudtshoorn, and N. Gericke, Medicinal Plants of South Africa, Briza Publications, Pretoria, South Africa, 1997.

[30] I. M. S. Eldeen, E. E. Elgorashi, and J. Van Staden, "Antibacterial, anti-inflammatory, anti-cholinesterase and mutagenic effects of extracts obtained from some trees used in South African traditional medicine," Journal of Ethnopharmacology, vol. 102, no. 3, pp. 457-464, 2005.

[31] F. W. Muregi, A. Ishih, T. Miyase et al., "Antimalarial activity of methanolic extracts from plants used in Kenyan ethnomedicine and their interactions with chloroquine (CQ) against a CQtolerant rodent parasite, in mice," Journal of Ethnopharmacology, vol. 111, no. 1, pp. 190-195, 2007.

[32] S. F. Van Vuuren and D. Naidoo, "An antimicrobial investigation of plants used traditionally in southern Africa to treat sexually transmitted infections," Journal of Ethnopharmacology, vol. 130, no. 3, pp. 552-558, 2010.

[33] J. T. Mukinda and P. F. K. Eagles, "Acute and sub-chronic oral toxicity profiles of the aqueous extract of Polygala fruticosa in female mice and rats," Journal of Ethnopharmacology, vol. 128, no. 1, pp. 236-240, 2010.

[34] B. T. S. Yff, K. L. Lindsey, M. B. Taylor, D. G. Erasmus, and A. K. Jäger, "The pharmacological screening of Pentanisia prunelloides and the isolation of the antibacterial compound palmitic acid," Journal of Ethnopharmacology, vol. 79, no. 1, pp. 101-107, 2002.

[35] A. K. Jäger, A. Hutchings, and J. Van Staden, "Screening of Zulu medicinal plants for prostaglandin-synthesis inhibitors," Journal of Ethnopharmacology, vol. 52, no. 2, pp. 95-100, 1996.

[36] J. M. Watt and M. G. Breyer-Brandwijk, The Medicinal and Poisonous Plants of Southern Eastern Africa, Churchill Livingstone, Edinburgh, Scotland, 1962. 
[37] S. P. N. Mativandlela, J. J. M. Meyer, A. A. Hussein, P. J. Houghton, C. J. Hamilton, and N. Lall, "Activity against Mycobacterium smegmatis and $M$. tuberculosis by extract of South African medicinal plants," Phytotherapy Research, vol. 22, no. 6, pp. 841-845, 2008.

[38] L. V. Buwa and A. J. Afolayan, "Antimicrobial activity of some medicinal plants used for the treatment of tuberculosis in the Eastern Cape Province, South Africa," African Journal of Biotechnology, vol. 8, no. 23, pp. 6683-6687, 2009.

[39] T. York, S. F. Van Vuuren, and H. de Wet, "An antimicrobial evaluation of plants used for the treatment of respiratory infections in rural Maputaland, KwaZulu-Natal, South Africa," Journal of Ethnopharmacology, vol. 144, no. 1, pp. 118-127, 2012.

[40] I. M. S. Eldeen and J. Van Staden, "Antimycobacterial activity of some trees used in South African traditional medicine," South African Journal of Botany, vol. 73, no. 2, pp. 248-251, 2007.

[41] J. N. Eloff, "A sensitive and quick microplate method to determine the minimal inhibitory concentration of plant extracts for bacteria," Planta Medica, vol. 64, no. 8, pp. 711-713, 1998.

[42] G. P. S. Jadaun, C. Agarwal, H. Sharma et al., "Determination of ethambutol MICs for Mycobacterium tuberculosis and Mycobacterium avium isolates by resazurin microtitre assay," Journal of Antimicrobial Chemotherapy, vol. 60, no. 1, pp. 152-155, 2007.

[43] A. R. Ndhlala, G. I. Stafford, J. F. Finnie, and J. Van Staden, "In vitro pharmacological effects of manufactured herbal concoctions used in KwaZulu-Natal South Africa," Journal of Ethnopharmacology, vol. 122, no. 1, pp. 117-122, 2009.

[44] C. W. Fennell, K. L. Lindsey, L. J. McGaw et al., "Assessing African medicinal plants for efficacy and safety: pharmacological screening and toxicology," Journal of Ethnopharmacology, vol. 94, no. 2-3, pp. 205-217, 2004.

[45] S. Voravuthikunchai, A. Lortheeranuwat, W. Jeeju, T. Sririrak, S. Phongpaichit, and T. Supawita, "Effective medicinal plants against enterohaemorrhagic Escherichia coli O157:H7," Journal of Ethnopharmacology, vol. 94, no. 1, pp. 49-54, 2004.

[46] R. B. Mulaudzi, A. R. Ndhlala, J. F. Finnie, and J. Van Staden, "Antimicrobial, anti-inflammatory and genotoxicity activity of Alepidea amatymbica and Alepidea natalensis (Apiaceae)," South African Journal of Botany, vol. 75, no. 3, pp. 584-587, 2009.

[47] J. J. Nair, A. O. Aremu, and J. Van Staden, "Anti-inflammatory effects of Terminalia phanerophlebia (Combretaceae) and identification of the active constituent principles," South African Journal of Botany, vol. 81, pp. 79-80, 2012.

[48] S. Feleke and A. Brehane, "Triterpene compounds from the latex of Ficus sur I," Bulletin of the Chemical Society of Ethiopia, vol. 19, no. 2, pp. 307-310, 2005.

[49] J. S. Negi, P. Singh, G. Joshi, M. S. Rawat, and V. Bisht, “Chemical constituents of Asparagus," Pharmacognosy Reviews, vol. 4, no. 8, pp. 215-220, 2010.

[50] D. J. Taur and R. Y. Patil, "Mast cell stabilizing and antiallergic activity of Abrus precatorius in the management of asthma," Asian Pacific Journal of Tropical Medicine, vol. 4, no. 1, pp. 4649, 2011.

[51] S. G. Sparg, M. E. Light, and J. Van Staden, "Biological activities and distribution of plant saponins," Journal of Ethnopharmacology, vol. 94, no. 2-3, pp. 219-243, 2004.

[52] X. Luo, D. Pires, J. Ainsa et al., "Antimycobacterial evaluation and preliminary phytochemical investigation of selected medicinal plants traditionally used in Mozambique," Journal of Ethnopharmacology, vol. 137, no. 1, pp. 114-120, 2011. 


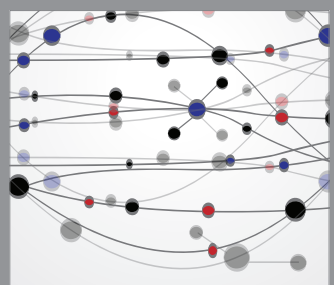

The Scientific World Journal
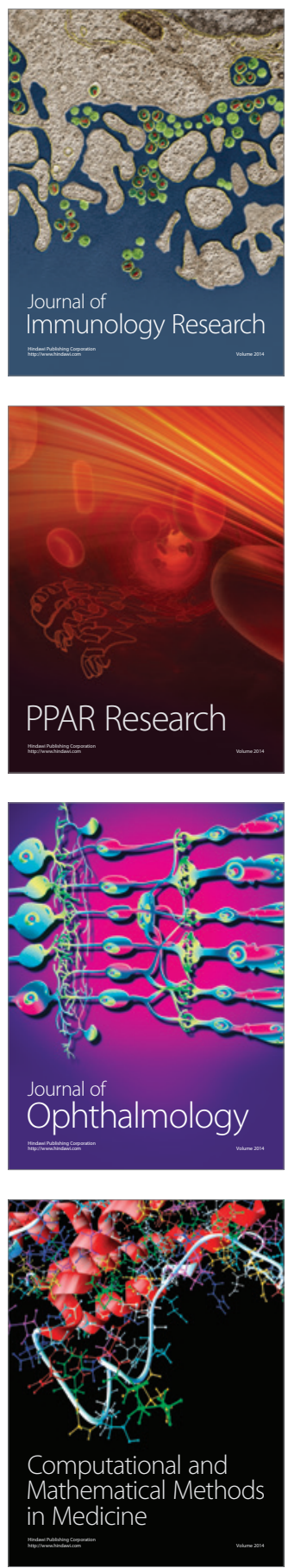

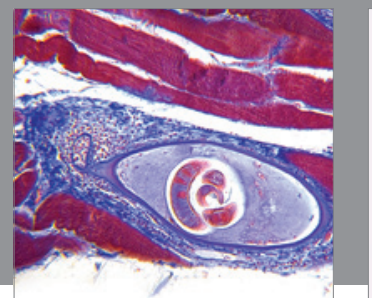

Gastroenterology

Research and Practice
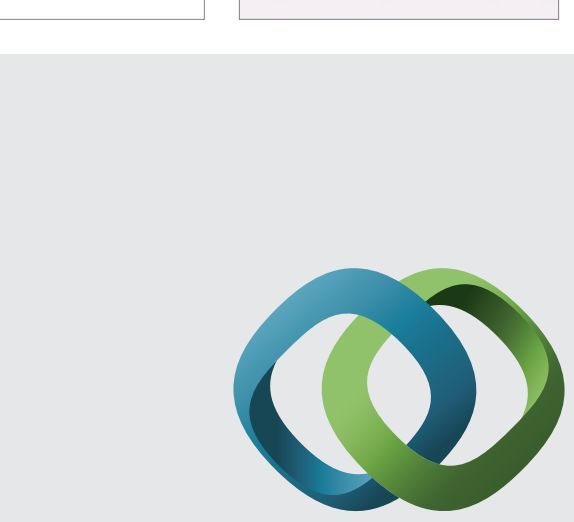

\section{Hindawi}

Submit your manuscripts at

http://www.hindawi.com
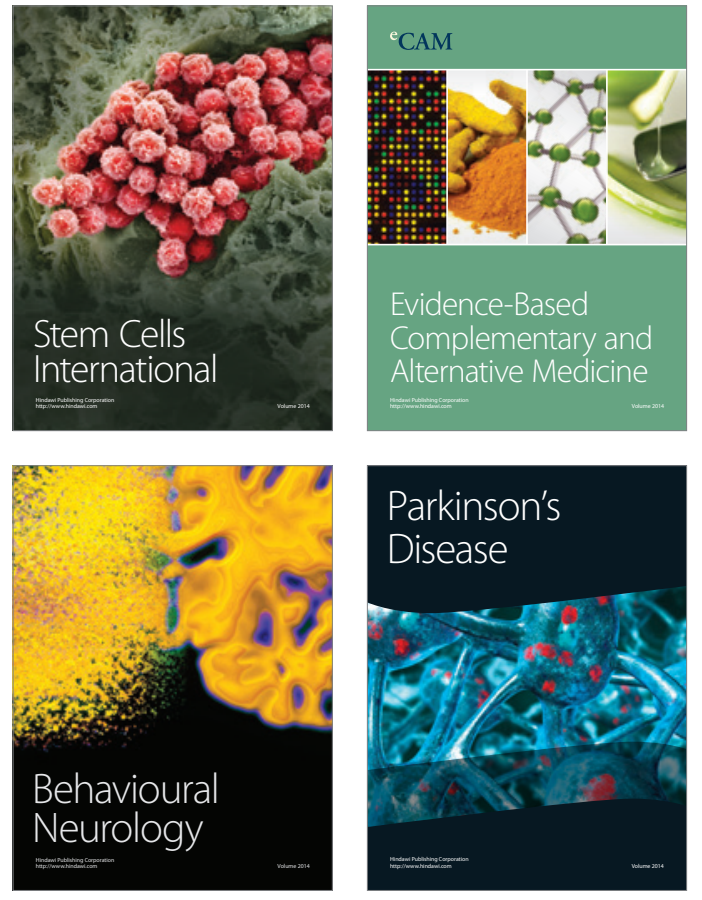
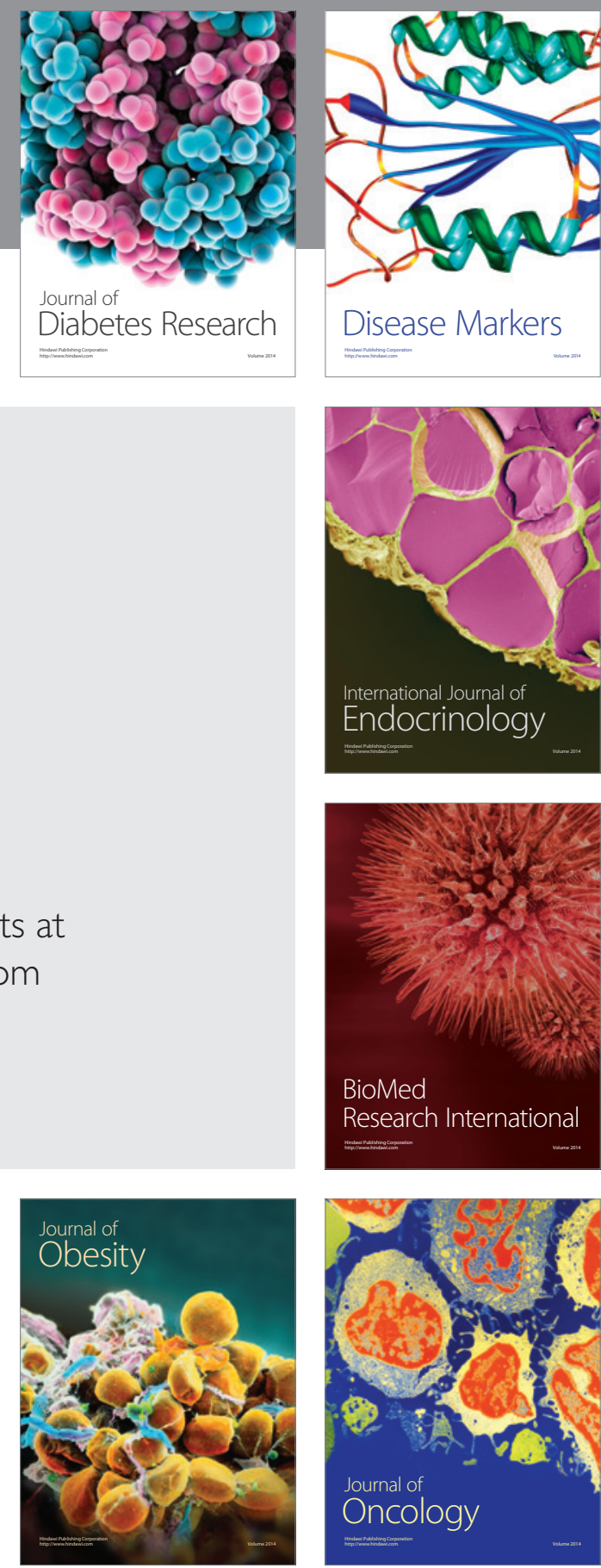

Disease Markers
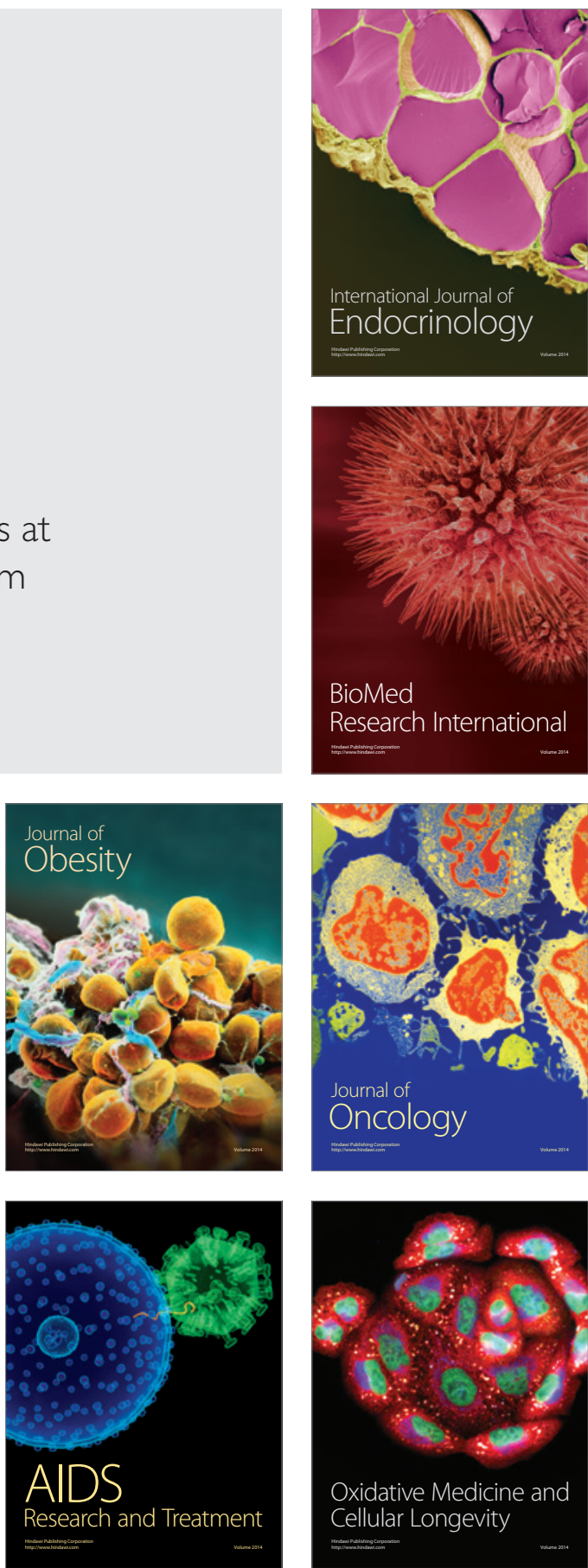